\title{
PENGEMBANGAN LEMBAR KERJA PESERTA DIDIK BERBASIS LINGKUNGAN SEKITAR SEBAGAI UPAYA UNTUK MENINGKATKAN PEMAHAMAN SISWA SMP TENTANG KONSEP IDENTIFIKASI MAKHLUK HIDUP
}

\author{
Reni Mustika ${ }^{*}$, Bhakti Karyadi ${ }^{1}$, Abdul Rahman Singkam ${ }^{1}$ \\ ${ }^{1}$ Program Studi Pendidikan Biologi, Fakultas Keguruan dan Ilmu Pendidikan, Universitas Bengkulu \\ Email: Rhenymustika26@yahoo.com
}

\begin{abstract}
Abstrak
Penelitian ini bertujuan untuk mengetahui peningkatan pemahaman peserta didik yang dilakukan secara kelompok berdasarkan kemampuan siswa dalam mengerjakan atau menjawab bahan diskusi pada LKPD. Penelitian dilakukan dengan 3 tahap yaitu 1). Validasi berupa analisis kebutuhan pengembangan materi IPA Biologi berdasarkan kurikulum 13 dan lingkungan sekitar; 2). Pengembangan desain LKPD berdasarkan analisis kebutuhan; dan 3). Uji coba terbatas LKPD pada peserta didik. Subjek penelitian ini sebanyak 30 peserta didk kelas $\mathrm{VII}_{\mathrm{A}}$ Sekolah Menengah Pertama (SMP) Negeri 17 Bengkulu Tengah. Instrumen yang digunakan adalah lembar instrumen validasi untuk mengetahui kelayakan LKPD dari ahli dan bahan ajar LKPD untuk mengukur pemahaman siswa. Berdasarkan hasil validasi, LKPD yang disusun sangat layak digunakan dengan nilai rata-rata sebesar $85 \%$. Uji coba skala terbatas menunjukkan bahwa LKPD ini efektif secara kelompok dengan nilai tertinggi sebesar $90 \%$ yang terletak pada level menyimpulkan. Berdasarkan hasil validasi dan uji coba tersebut, LKPD yang dikembangkan ini layak digunakan sebagai bahan ajar materi keanekaragaman makhluk hidup kelas VII SMP.
\end{abstract}

Kata kunci: Pemahaman Siswa, Pengembangan LKPD, Uji Coba

\begin{abstract}
This study aims to determine the increase in students understanding conducted in groups based on ability of students to work on or answer the discussion material at the worksheet. The research was conducted in 3 stages, namely 1). Validation in the form of analyzing the need to develop Biology science materials based on curriculum 13 and the surrounding environment; 2). Development of LKPD design based on needs analysis; and 3). Limited LKPD trials on students. The subjects of this study were 30 participants in class VIIA Middle School (SMP) Negeri 17 Bengkulu Tengah. The instrument used was a validation instrument sheet to determine the feasibility of the LKPD from experts and LKPD teaching materials to measure student understanding. Based on the results of the validation, the compiled LKPD is very feasible to use with an average value of $85 \%$. Limited scale trial also show this LKDP efective in group with the highest value of $90 \%$ which is located at the level of conclude. The highest learners understanding in group on the conclusion level, and individually on the giving description level. Based on the valadation result and that trial, LKDP this developed is feasible used as material teaching diversity of living things class VII SMP.
\end{abstract}

Keywords: Understanding of Students, Development of LKPD, Trials 


\section{PENDAHULUAN}

Indonesia memiliki sumber daya perairan tawar yang sangat luas. Luas perairan tawar di Indonesia yang terdiri atas danau, rawa dan sungai berkisar $60.252,92 \mathrm{~km}^{2}$ (Kementrian Kelautan dan Perikanan, 2015). Salah satu provinsi di Indonesia yang memiliki sumber daya perairan tawar yang cukup luas adalah Bengkulu. Provinsi Bengkulu memiliki sekitar 11 danau dengan luas mencapai $2.174,21 \mathrm{~km}^{2}$ (Kementrian PUPR, 2017). Sungai yang berada di Provinsi Bengkulu antara lain Sungai Selagan, Sungai Sengaur Sungai Ketahun, Air Bantal, Air Seluma, Air Alas dan lainnya (Status Lingkungan Hidup Daerah, 2014). Sumber daya perairan yang luas ini dapat dimanfaatkan dibidang pendidikan.

Bidang

pendidikan

keanekaragaman makhluk hidup dapat dimanfaatkan sebagai sumber belajar dengan menggunakan pembelajaran kontekstual. Menurut Karyadi (2016) pembelajaran kontekstual suatu sistem pembelajaran yang mengaitkan subjek yang dipelajari dengan kondisi dunia nyata, sehingga peserta didik dapat mengaplikasikan pengetahuan, pengalaman ke kehidupan sehari-hari.

Pembelajaran menggunakan pendekatan kontekstual merupakan konsep pembelajaran yang memanfaatkan lingkungan sebagai sumber belajar. Menurut Lilawati (2017) sumber belajar adalah segala sesuatu yang dapat digunakan untuk memperoleh pengetahuan, pengalaman, dan keterampilan agar tujuan belajar dapat tercapai. Sesuatu yang dapat dijadikan sebagai sumber belajar di lingkungan dapat berupa Lembar Kerja Peserta Didik
(LKPD), buku pelajaran, handout, modul, dan lainnya.

Berdasarkan hasil observasi terhadap guru dan peserta didik di SMP Negeri 17 Bengkulu Tengah menunjukan bahwa guru belum menggunakan LKPD berbasis lingkungan sekitar sebagai sumber belajar. Pembelajaran yang berlangsung di kelas hanya menggunakan buku paket. Selain itu, wawancara peneliti dengan guru IPA di SMP tersebut menunjukkan bahwa pembelajaran IPA jarang menggunakan LKPD baik dari lembaga penerbit maupun LKPD buatan sendiri dikarenakan keterbatasan sarana dan prasarana. LKPD berbahan lokal yang berada di sekitar sekolah seharusnya dapat digunakan untuk mengatasi kendala fasilitas pembelajaran yang masih minim, sehingga dapat menunjang proses pendidikan.

Pembelajaran di sekolah berlangsung hanya menggunakan metode ceramah dan diskusi. Kondisi pembelajaran seperti ini menjadikan proses pembelajaran lebih menoton, membosankan dan guru lebih berperan aktif dari pada peserta didik. Sedangkan dalam kurikulum 2013 menuntut peserta didik lebih berperan aktif dalam mengembangkan pengetahuan dan kecakapan yang dimiliki dengan mengeksplorasi semua sumber belajar yang ada. Berdasarkan hal tersebut guru mengharapkan adanya bahan ajar yang dapat menunjang proses pembelajaran yang ada di sekolah baik dari kreativitas guru ataupun dari lembaga penerbit.

Pemanfaatan lingkungan sebagai sumber belajar dapat dikembangkan dalam bentuk sebuah bahan ajar. Bahan ajar berperan dalam membantu pelaksanaan kegiatan belajar mengajar di kelas. Pembelajaran yang memanfaatkan 
lingkungan sekitar dapat menunjang proses perkembangan peserta didik secara utuh karena melibatkan secara langsung aspek kognitif, afektif, dan psikomotor (Karyadi, 2016). Artinya seorang guru yang profesional dituntut kreativitasnya untuk mampu menyusun bahan ajar yang inovatif, menarik, kontekstual dan sesuai dengan kebutuhan peserta didik. Oleh karena itu, bahan ajar yang dapat dimanfaatkan baik guru maupun peserta didik salah satu instrumen pembelajaran yang dapat meningkatkan hasil belajar.

Salah satu bahan ajar yang dapat dikembangkan guru adalah Lembar Kerja Peserta Didik (LKPD). LKPD merupakan bahan ajar cetak yang dapat dikembangkan oleh guru yang berupa lembaran-lembaran kertas yang berisi materi, ringkasan, dan tugas pembelajaran yang harus dikerjakan oleh peserta didik. LKPD digunakan biasanya sebagai bahan ajar yang mempermudah peserta didik untuk berinteraksi dengan materi yang diberikan, melatih kemandirian belajar peserta didik, dan memudahkan guru dalam memberikan tugas kepada peserta didik (Prastowo, 2015). Berdasarkan hal tersebut, LKPD merupakan bahan ajar yang penting dikembangkan oleh guru sebagai penunjang kegiatan pembelajaran di sekolah. Guru diharapkan mampu mengembangan LKPD yang memanfaatkan lingkungan sekitar dengan mengaitkan fakta-fakta yang terdapat disekitar peserta didik.

Berdasarkan adanya permasalahan di atas peneliti mengembangkan bahan ajar LKPD berdasarkan sumber belajar yang memanfaatkan potensi lokal di lingkungan perairan tawar yaitu Sungai Sengaur yang berada di dekat lingkungan sekitar SMP Negeri 17 Bengkulu Tengah.
Salah satu potensi lokal perairan tawar yang dapat dijadikan sumber belajar adalah keragaman makroinvertebrata di perairan sungai.

Makroinvertebrata merupakan salah satu hewan animalia yang hidup di dasar perairan. Makroinvertebrata juga dikatakan semua anggota animalia yang tidak memiliki tulang belakang yang berukuran 3-5 $\mathrm{mm}$ yang hidup pada lumpur, pasir, batu-batuan, maupun sampah organik baik di dasar perairan laut, sungai, danau atau kolam, merupakan organisme menempel, memendam, melata, dan meliang di dasar perairan (Khusna, 2018). Keragaman makroinvertebrata yang berada di lingkungan sekitar dapat digunakan sebagai sumber belajar berbasis lingkungan, terutama dalam mata pelajaran IPA jenjang Sekolah Menengah Pertama (SMP).

Berdasarkan hasil penelitian Mustika (2019) ditemukan 38 jenis spesies makro invertebrata dari 34 famili yang tersebar di lingkungan sekitar Sungai Sengaur. Tingginya keragaman yang ditemukan dapat dimanfaatkan sebagai bahan ajar. Pengembangan bahan ajar berupa LKPD mengenai makroinvertebrata di Sungai Sengaur Kabupaten Bengkulu Tengah ini dapat diterapkan dalam pembelajaran Biologi di SMP pada materi invertebrata. Pembelajaran menggunakan LKPD membantu peserta didik untuk mengkonstruksi pengetahuan ke dalam otak mereka melalui tahapan berpikir (Maryati, 2018). Hal ini sejalan dengan tujuan penelitian ini adalah mengetahui kelayakan LKPD yang dikembangkan sebagai bahan ajar dan mengetahui tingkat pemahaman peserta didik pada materi keanekaragaman makhluk hidup sub materi Invertebrata dikelas VII SMP. 


\section{METODE}

Metode yang digunakan dalam penelitian ini adalah metode penelitian dan pengembangan (Research and Development). Penelitian ini telah dilaksanakan pada Bulan 27 Maret 2019 di SMPN 17 Bengkulu Tengah. Subjek uji coba dalam penelitian ini adalah tiga orang validator yang terdiri dari dua orang dosen Pendidikan Biologi Universitas Bengkulu dan satu guru SMP, serta 30 peserta didik kelas VII SMPN 17 Bengkulu Tengah. Teknik pengumpulan data dalam penelitian ini menggunakan 3 tahap yaitu tahap validasi yaitu perencanaan melakukan analisis kebutuhan antara lain analisis materi IPA Biologi berdasarkan kurikulum 13 dan lingkungan sekitar sebagai sumber belajar, pengembangan desain LKPD berdasarkan analisis kebutuhan, dan uji coba terbatas pada peserta didik.

Nilai akhir validator dan persentase pemahaman peserta didik ini diinterpretasikan dengan menggunakan panduan tabel kriteria interpretasi kelayakan dan pemahaman konsep Riduwan (2015) dapat dilihat pada Tabel 1.

Tabel 1. Kriteria Intepretasi kelayakan LKPD

Skor Rerata (\%)
Kriteria Respon Kelayakan

Sangat Tidak Layak
Tidak Layak
Cukup Layak
Layak
Sangat Layak

Kriteria Pemahaman

Sangat Baik
Baik
Cukup
Kurang

Sangat Kurang

\section{HASIL DAN PEMBAHASAN}

Menurut Kemendikbud No 24 tahun

2016, materi keanekaragaman makhluk hidup dengan Kompetensi Dasar 3.2 yaitu "Mengklasifikasikan makhluk hidup berdasarkan karakteristik yang diamati". Berdasarkan analisis kurikulum, kompetensi dasar, dan kebutuhan, maka LKPD dengan materi makroinvertebrata diharapkan mampu mencapai kompetensi tersebut. Tujuan pembelajaran yang ingin dicapai antara lain:

a. Peserta didik menjelaskan atau mengidentifikasi konsep keanekaragaman makhluk hidup dari pengamatan makroinvertebrata.

b. Peserta didik mampu membedakan konsep keanekaragaman makhluk hidup dari tingkat takson filum, kelas, dan spesies melalui karakteristik jenis makroinvertebrata. c. Peserta didik dapat menganalisis konsep keanekaragaman makhluk hidup dari tingkat takson filum, kelas melalui identifikasi jenis makroinvertebrata.

d. Peserta didik mampu menyimpulkan konsep kenaekaragaman makhluk hidup berdasarkan pengamatan yang telah dilakukan.

Salah satu keragaman makhluk hidup yang berada di lingkungan sekitar adalah keragaman makroinvertebrata. Keragaman makroinvertebrata yang dominan ditemukan di lingkungan sekitar sekolah adalah Insekta/serangga (Anthropoda) dan Gastropoda (Mollusca). Berdasarkan penelitian Mar'i (2017; Zulkifli, 2011) terdahulu menyatakan bahwa insekta dan mollusca merupakan sumber belajar yang cocok digunakan dibidang pendidikan karena hewan tersebut memiliki kemampuan adaptasi yang baik terhadap berbagai kondisi lingkungan dan memiliki 
jumlah yang lebih banyak dibandingkan hewan lainnya serta mudah ditemukan.

Keragaman yang ditemukan tersebut dapat digunakan sebagai sumber belajar berbasis lingkungan, terutama dalam mata pelajaran IPA jenjang Sekolah Menengah Pertama (SMP) dan pemanfaatan lingkungan sebagai bahan ajar dapat dikembangkan antara lain dalam bentuk Lembar Kerja Peserta Didik (LKPD).

Pembelajaran mengenai keragaman makroinvertebrata yang dikaitkan dengan materi identifikasi makhluk hidup dengan lingkungan pada peserta didik SMP dimaksudkan untuk memperkenalkan keragaman makhluk hidup atau makroinvertebrata di lingkungan kehidupan sehari-hari, sebagaimana menurut Hariyanti (2008) dengan adanya materi pembelajaran makhluk hidup secara langsung yang dialami melalui kegiatan pembelajaran menjadikan peserta didik dapat lebih membangun makna dalam memori, dan dapat menambah pengetahuan, pengalaman bagi peserta didik. Hal ini berarti dengan adanya keragaman makroinvertebrata tersebut sangat sesuai pembelajaran IPA Biologi dengan materi keanekaragaman atau identifikasi makhluk hidup sub materi invertebrata.

Berdasarkan hasil analisis data angket validasi LKPD Biologi yang telah dilakukan uji validasi oleh dua Dosen ahli yaitu Dosen Pendidikan Biologi, serta satu orang guru SMP Negeri 17 Bengkulu Tengah. Secara keseluruhan hasil rata-rata persentase pada tiap aspek dari tim dosen dan guru menunjukan bahwa LKPD ini sangat layak digunakan sebagai bahan ajar materi invertebrata kelas VII SMPN 17 Bengkulu Tengah disajikan pada Tabel 2.

Tabel 2.Persentase validasi LKPD oleh validator.

\begin{tabular}{|c|c|}
\hline Aspek Penilaian & Presentase (\%) \\
\hline Kelayakan isi & Sangat Layak \\
\hline Penyajian & Sangat Layak \\
\hline Kebahasaan & Sangat Layak \\
\hline Kegrafikan & 91 \\
\hline Rata-rata persentase & Sangat Layak \\
\hline Berdasarkan Tabel 2 hasil analisis & LKPD yang dibuat \\
\hline data menunjukan bahwa tiap aspek yang & menggambarkan keseluruhan dari secara \\
\hline $\begin{array}{l}\text { dinilai dosen dan guru, menyatakan } \\
\text { bahwa desain LKPD yang dikembangkan } \\
\text { dinilai sangat layak dengan nilai rata-rata }\end{array}$ & $\begin{array}{l}\text { sistematis yang ditampilkan pada setiap } \\
\text { halaman. Sistematika hasil desain atau } \\
\text { kerangka LKPD dibuat berdasarkan hasil }\end{array}$ \\
\hline sebesar $87 \%$. Validasi LKPD dinilai & analisis kurikulum, kompetensi dasar, dan \\
\hline berdasarkan beberapa komponen & kebutuhan peserta didik. Urutan \\
\hline $\begin{array}{l}\text { meliputi aspek kelayakan isi, kelayakan } \\
\text { penyajian, kelayakan kebahasaan, dan } \\
\text { kelayakan kegrafisan (Depdiknas, 2008). }\end{array}$ & $\begin{array}{l}\text { penyajian LKPD disajikan sebagai berikut: } \\
\text { judul, kompetensi dasar, tujuan, materi, } \\
\text { alat dan bahan, langkah kerja, tabel hasil }\end{array}$ \\
\hline $\begin{array}{l}\text { Struktur lembar kerja yang telah di } \\
\text { rancang berdasarkan diversitas atau }\end{array}$ & $\begin{array}{l}\text { pengamatan, bahan/pertanyaan diskusi, } \\
\text { kesimpulan, dan suplemen/artikel. }\end{array}$ \\
\hline keragaman makroinvertebrata yang ada di & Struktur LKPD \\
\hline $\begin{array}{l}\text { lingkungan sekitar sekolah dinilai layak } \\
\text { untuk dijadikan sebagai bahan ajar untuk } \\
\text { peserta didik. }\end{array}$ & $\begin{array}{l}\text { mengacu pada Depdikbud (2008) yang } \\
\text { terdiri atas judul, petunjuk, belajar, } \\
\text { kompetensi }\end{array}$ \\
\hline
\end{tabular}


dicapai, informasi pendukung, langka kerja, tugas, dan penilian. Desain kerangka LKPD dapat dilihat pada Gambar 1.

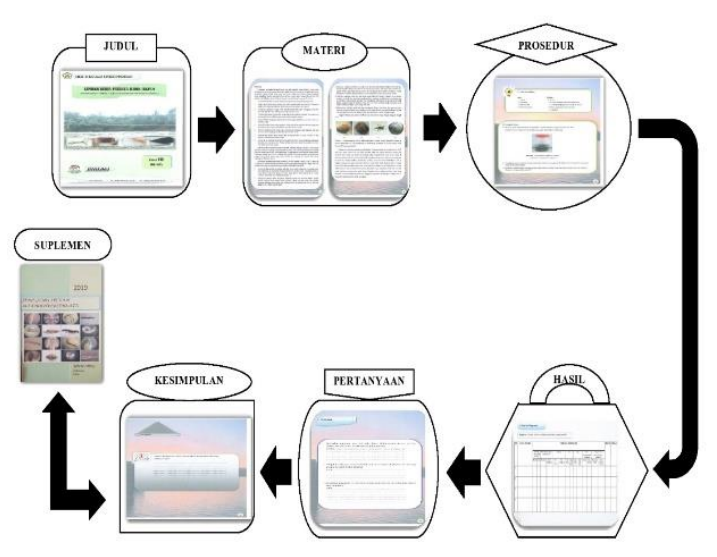

Gambar 1. Kerangka LKPD

Desain LKPD yang telah divalidasi oleh validator dinilai sangat layak. Kelayakan LKPD ditinjau dari aspek kedalaman materi, ketepatan kompetensi, desain dan kebahasaaan. Beberapa poin yang perlu diperbaiki berdasarkan saran dan arahan dari ketiga validator sebelum LKPD dilanjutkan ke uji coba oleh peserta didik antara lain sebagai berikut:

1. Melengkapi data kompetensi dasar pada bagian cover judul

2. Memperbaiki penggunaan imbuhan "di" yang menunjukan keterangan tempat atau kata kerja misalnya: di atas, di samping, dan di bawah

3. Mengurangi emoticon yang tidak berkaitan dengan materi yang akan di sampaikan karena dapat mengganggu konsentrasi peserta didik

4. Melengkapi data pada konsep materi, misalnya menambahkan gambar makroinvertebrata lain dan menambahkan kelas dari filum Anthropoda dan Mollusca di bagian konsep materi.

Berdasarkan saran dan arahan di atas terdapat beberapa halaman yang perlu diperbaiki dan yang telah diperbaiki dari validator dapat dilihat pada Tabel 3.

Tabel 3. Perbedaan LKPD Sebelum Revisi dan Setelah Revisi

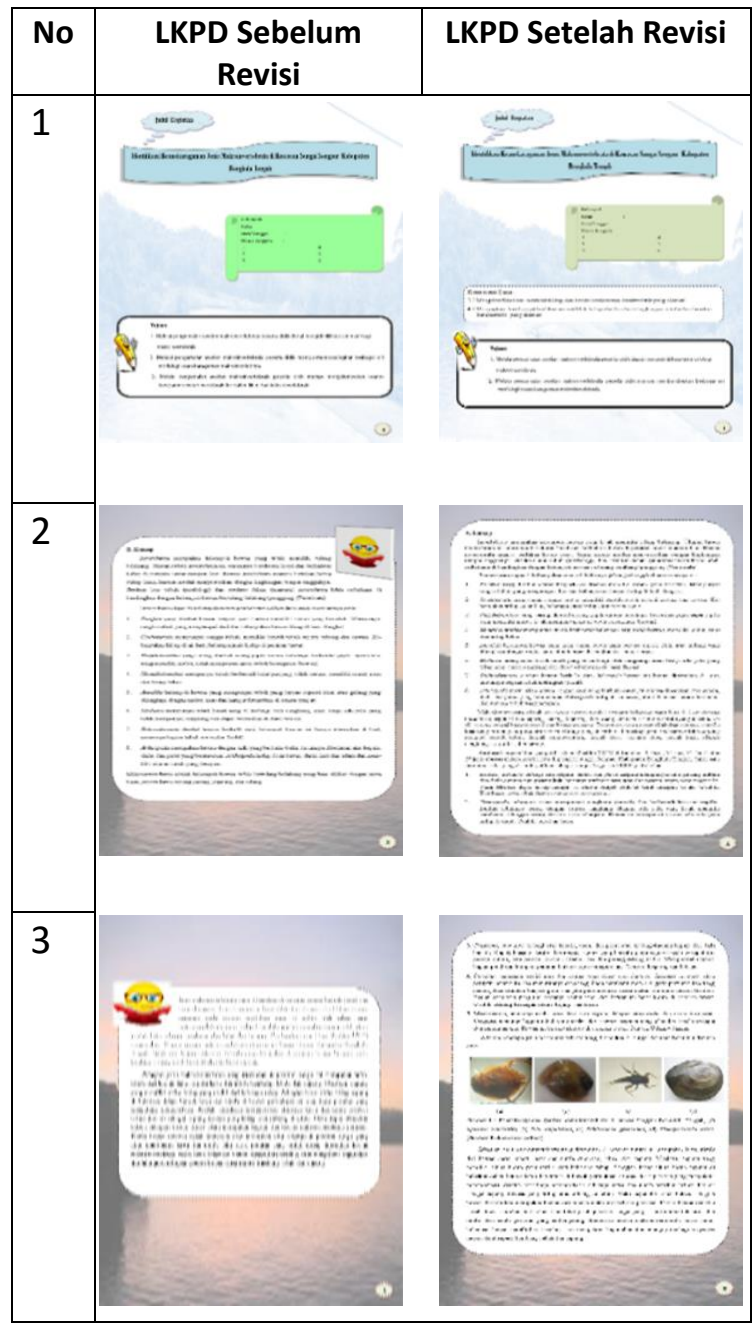

LKPD hasil validasi ini memiliki keunggulan berupa memperkenalkan keanekaragaman makroinvertebrata yang berada dilingkungan sekitar, memberikan pengalaman atau meningkatkan rasa ingin tahu peserta didik terhadap pembelajaran, dan membuat pembelajaran tidak membosankan sehingga peserta didik semangat dalam mengikuti pembelajaran. Melalui bantuan LKPD ini, peserta didik akan melakukan percobaan untuk menemukan konsep secara mandiri (Trisna, 2018). 
Setelah desain LKPD direvisi kemudian LKPD dilakukan uji coba skala terbatas pada 30 peserta didik kelas $\mathrm{VII}_{\mathrm{A}}$ SMP Negeri 17 Bengkulu Tengah. Uji coba LKPD dilakukan untuk melihat peningkatan hasil belajar terhadap LKPD yang dikembangkan dengan cara menilai peningkatan pemahaman peserta didik yang dilakukan secara kelompok berdasarkan kemampuan siswa dalam mengerjakan atau menjawab bahan diskusi pada LKPD.

Peningkatan mencakup 3 indikator yaitu level memberikan penjelasan, membedakan, dan menyimpulkan. Pemahaman peserta didik secara kelompok dinilai sangat baik dengan nilai rata-rata $84 \%$, dapat dilihat pada Tabel 3. Pemahaman tingkat tertinggi peserta didik secara kelompok dinyatakan sangat baik pada level "menyimpulkan" dengan indeks sebesar 90\%, sedangkan pemahaman tingkat terendah peserta didik dinyatakan cukup pada level "mengidentifikasi" dengan indeks sebesar $68 \%$, dapat dilihat pada Tabel 3.

Tabel 3. Nilai rata-rata pemahaman peserta didik secara klasikal.

\begin{tabular}{cccc}
\hline No & Level & Nilai Rerata (\%) & Kriteria \\
\hline $\mathbf{1}$ & Mengidentifikasi & 68 & Cukup \\
$\mathbf{2}$ & Mampu Membedakan & 88 & Sangat Baik \\
$\mathbf{3}$ & Mampu Menganalisis & 87 & Sangat Baik \\
$\mathbf{4}$ & Menyimpulkan & 90 & Sangat Baik \\
\hline & Nilai rata-rata secara klasikal & $\mathbf{8 4}$ & Sangat Baik \\
\hline
\end{tabular}

Berdasarkan Tabel 3. menunjukan bahwa LKPD mampu memberdayakan pahamahaman pesertas didik. Nilai pemahaman peserta didik secara kelompok, diperoleh hasil bahwa dari keempat level menunjukan persentase nilai tertinggi terletak pada level "menyimpulkan". Hal ini dibuktikan dengan nilai $90 \%$ peserta didik telah mampu menyimpulkan hasil pengamatan dan bahan diskusi yang telah dilakukan. Tingginya level ini diduga LKPD dan bahan diskusi yang diberikan ini berkaitan dengan kemampuan peserta didik dalam menjawab bahan diskusi. Peserta didik mampu mengaitkan atau menarik kesimpulan berdasarkan data hasil pengamatan untuk mencapai tujuan kegiatan atau peserta didik akan mampu menemukan inti yang paling mendasar dari materi yang telah dipelajari. Peserta didik kelas VII yang berusia 12-13 tahun merupakan tahapan awal dari operasional konkrit, dimana pada tahapan ini peserta didik sudah memiliki kemampuan mengamati, mengumpulkan fakta dan menyimpulkan sesuatu berdasarkan informasi yang mereka dapatkan (Karyadi, 2018; Ramlah, 2015).

Berdasarkan hal tersebut, uji coba skala terbatas setelah diberikan bahan ajar berupa LKPD dinyatakan tuntas secara klasikal. Jadi, pembelajaran dengan menggunakan bahan ajar yang berbasis lingkungan pada konsep identifikasi makhluk hidup yang telah dikembangkan dapat meningkatkan kemampuan pemahaman kognitif peserta didik.

Proses pembelajaran yang menggunakan bahan ajar berbasis lingkungan akan melibatkan peserta didik lebih aktif, menumbuhkan rasa ingin tahu peserta didik dan mendorong peserta didik untuk mengkontruksikan pemahamannya dengan mengenalkan kondisi lingkungan, 
pengamatan terhadap lingkungan sekitar sehingga akan menimpulkan suatu masalahmasalah, sehingga dalam pembelajaran terjadi proses konstruksi pengetahuan pada diri peserta didik (Setiyadi, 2017; Karyadi, 2016). Artinya peserta didik dapat menerapkan pengetahuan berdasarkan fenomena yang ditemukan di lingkungan sekitar.

Tingginya nilai level ini tidak terlepas dari LKPD yang dikembangkan berdasarkan konten-konten yang dekat dengan peserta didik, umum diketahui sebagai pembelajaran lingkungan atau kontekstual. Pembelajaran kontekstual tentunya lebih melibatkan peserta didik membangun sendiri pengetahuan, konsep, teori berdasarkan pengamatan belajar mereka dan peserta didik dapat menerapkan pengetahuan yang didapatkan dalam proses pembelajaran dalam kehidupan sehari-hari berdasarkan pengalaman belajar yang dipelajari dengan kehidupan nyata (Zukmadini, 2018; Karyadi, 2016; 2018).

Secara keseluruhan hasil kemampuan pemahaman peserta didik secara kelompok sudah menunjukkan sebuah peningkatan, hal ini diduga karena pembelajaran dengan bahan ajar berupa LKPD membuat peserta didik aktif, berpikir kreatif dan membantu peserta didik menemukan konsep. Bahan ajar yang menghubungan proses pembelajaran dengan konten lingkungan akan menumbuhkan kemampuan berpikir kritis, kreatif, komunikatif, dan mampu kalaboratif (Karyadi, 2017). Dengan adanya bahan ajar yang disusun berdasarkan pendekatan kontekstualdapat meningkatkan hasil pemahaman peserta didik, pembelajaran dengan bantuan bahan ajar dapat memotivasi peserta didik untuk belajar secara aktif, memberikan pengalaman positif dan pengaruh yang penting bagi peserta didik (Zukmadini, 2018; Karyadi, 2016; Setiyadi, 2017).

Penggunaan

LKPD

hasil

pengembangan yang dilakukan pada proses pembelajaran memberikan hasil yang sangat baik dikarenakan bahan ajar yang digunakan sesuai dengan pengetahuan peserta didik yang dapat mengetahui keterkaitaan antara pembelajaran dan hasil yang akan diperoleh. Hal ini tentu didukung kuat oleh penggunaan bahan ajar yang valid sehingga mengarahkan aktivitas peserta didik di dalam kelas, sehingga proses pembelajaran menjadi lancar, melatih kemampuan kinerja peserta didik, dan menumbuhkan perilaku positif terhadap respon dan kesadaran/peduli terhadap lingkungan (Arifuddin, 2017; Karyadi, 2017; Ekaputri, 2018). Bahan ajar hasil pengembangan ini dapat dikatakan valid dikarenakan dapat meningkatkan hasil pemahaman konsep peserta didik.

\section{PENUTUP}

\section{Simpulan}

Berdasarkan hasil desain LKPD yang disusun berdasarkan keragaman jenis makroinvertebrata di Sungai Sengaur, Bengkulu Tengah dinyatakan sangat layak oleh tiga validator dengan nilai presentase sebesar $85,7 \%$. Hasil uji coba peserta didik secara kelompok dari keseluruhan level dinyatakan sangat baik (90\%) terletak pada level menyimpulkan. Sedangkan hasil uji coba pemahaman peserta didik terendah dinyatakan cukup (68\%) terletak pada level mengidentifikasi.

\section{Saran}

Berdasarkan hasil penelitian yang dilakukan maka sebaiknya peneliti lanjutan perlu meningkatkan jenjang atau level mengidentifikasi. Pada level tersebut perlu dikembangkan bahan diskusi atau 
pertanyaan yang lebih spesifik dan mudah di pahami oleh peserta didik.

\section{UCAPAN TERIMA KASIH}

Terima kasih penulis ucapkan kepada Bapak Umaedi Heryan. M.Pd selaku Kepala Sekolah SMP Negeri 17 Bengkulu Tengah dan seluruh siswa kelas VII SMP Negeri 17 Bengkulu Tengah yang terlibat dalam uji coba.

\section{DAFTAR PUSTAKA}

Arifuddin, M., Abdul, S. M., \& Shofa, M. (2017). Pengembangan Bahan Ajar Berwawasan Lingkungan Bantaran Sungai Untuk Melatih Kemampuan 5M. Jurnal Sains dan Pendidikan Fisika. 1 (13): 248-254. (online). (http://ojs.unm.ac.id/JSdPF/article/d ownload/6194/3539), diakses $13 \mathrm{Juli}$ 2019.

Depdiknas.

(2008).

Panduan

7.(online).(https://iopscience.iop.o rg/article/10.1088/17426596/1116 /5/052018/pdf), diakses 23 juli 2019.

Hariyanti, E. (2006). Uji coba Model Pembelajaran Luar Ruang Mata Pelajaran IPA (Biologi). Jurnal Pendidikan. 1 (1). 106-114. (online). (http://www.jurnalpendidikan.uni pa.ac.id/ujicobamodel.html), diakses 1 Juli 2019.

Kemendikbud. (2016). Tentang Kompetensi Inti dan Kompetensi Dasar Kurikulum 2013 pada Pendidikan Dasar dan Menengah. Jakarta: Kemendikbud.

Kementrian Kelautan dan Perikanan. (2015). Kelautan dan Perikanan. Jakarta: Pusat Data Statistik dan Informasi.
Pengembangan Bahan Ajar. Jakarta: Direktorat Pembinaan SMA.

Ekaputri. R.Z., B Karyadi., N Anggraini., A Y Zukmadini., A Ruyani., \& W Zulistia. Behavior, paradigm, responses and concern Students' on the outdoor learning. Journal of Physics. 11 (16): 1 .

Karyadi. B., A. Ruyani., Sipriyadi., \& Johan, H. (2018). Impact of outdoorlearning by step Introduction, Exploration, and Interpretation(IEI)based on environment onstudents' critical thinking. Journal of Physics. 11 (16): 1-7. (online). (https://iopscience.iop.org/article/1 0.1088/17426596/1116/5/052036/p df), diakses 23 Juli 2019.

Statistik. Jakarta: Sekretarian Jenderal Pusat Data dan Teknologi Informasi (PUSDATIN

Kementrian PUPR. (2016). Buku Induk).

Lilawati, J. (2017). Analisis Pemanfaatan Sumber Belajar Dalam Proses

Karyadi. B., Endang. W.W., Meri.S., Winda. Z. (2017). Development of Biology Learning Strategy Based on Natural Environment in the Senior High School. Conference Proceeding BICSE. 978-602-8043-84-7: 450$456 . \quad$ (online). (http://repository.unib.ac.id/1668 2/1/Proceeding\%20BICSE\%202017. pdf), diakses 23 Juli 2019

Karyadi. B., Aceng. R., Agus. S., \& Selidin. D. (2016). Pembelajaran Sains Berbasis Kearifan Lokal Pada Sekolah Menengah Pertama Di Wilayah Bengkulu Selatan.Prosiding Seminar Nasional Pendidikan Sains (SNPS)VI. 231238.

(online). 
(https://media.neliti.com/media/p ublications/173652-IDpembelajaran-sains-berbasiskearifan-lok.pdf), diakses 23 Juli 2019.

Khusna. A. (2018). Studi Kualitas Air Sungai Sudimoro Di Mojokerto Berdasarkan Indeks Keanekaragaman Makrozoobentos Sebagai Sumber Belajar Biologi. [skripsi diterbitkan]. Malang: Universitas Muhammadiyah Malang.

Mar'i, H., Izmiarti., \& Nofrita. (2017). Komunitas Makrozoobentos di Sungai Gua Pintu Ngalau pada Kawasan Karst di Sumatera Barat. Jurnal Biologi Universita Andalas. 5 (1): 41-49. (online). (http://jbioua.fmipa.unand.ac.id/in dex.php/jbioua/article/download/2 08/193), diakses 13 Juli 2019.

Maryati., Ariefa. P., \& Sri. I. (2018). Pengembangan Lembar Kerja Siswa Berdasarkan Hasil Observasi Keanekaragaman Morfologi Tanaman Mangga (Mangifera Indica). Jurnal Pendidikan Biologi dan Pembelajaran Biologi. 2 (1): 68-75. (online). (https://ejournal.unib.ac.id/index.p hp/jppb/article/view/5144/2703), diakses 1 Juli 2019.

Mustika, R., Karyadi. B., \& Singkam. A. R. (2019). Keragaman dan Kelimpahan Makroinvertebrata di Sungai Sengaur Bengkulu Tengah. Prosiding Semirata BKS PTN Wilayah Barat Bidang MIPA. Bengkulu: 6-7 Juli 2019.

Prastowo, A. (2015). Panduan Kreatif Membuat Bahan Ajar Inovatif. Yogyakarta: DIVA Press.
Ramlah. (2015). Penerapan Teori Perkembangan Mental Piaget Tahap Operasional Konkret Pada Hukum Kekekalan Materi. Jurnal Pendidikan Unsika. 3 (2): 218-230. (online).(https://journal.unsika.ac.i d/index.php/judika/article/downlo ad/214/212), diakses 12 Juli 2019.

Riduwan, M. B. (2013). Skala Pengukuran Variabel-Variabel Penelitian. Bandung: Alfabeta.

Setiyadi, M. W. (2017). Pengembangan Modul Pembelajaran Biologi Berbasis Pendekatan Saintifik Untuk Meningkatkan Hasil Belajar Siswa. Journal of educational science and technology. 3 (2): 102112. (online). (http://ojs.unm.ac.id/JEST/article/ view/3468), diakses 13 Juli 2019.

SLHD Provinsi Bengkulu. (2014). Buku Data SLHD Provinsi Bengkulu. Bengkulu : Data Dinas Perikanan dan Kelauran Provinsi Bengkulu.

Trisna, D. M., Aceng. R., \& Yennita. (2018). Pengembangan Lembar Kerja Peserta Didik Untuk Menilai Kecenderungan Berperilaku Konservasi Kura-Kura. Jurnal Pendidikan Biologi dan Pembelajaran Biologi. 2 (2): 102107. (online). (https://ejournal.unib.ac.id/index.p hp/jppb/article/view/6815), diakses 1 Juli 2019.

Zukmadini, A. Y., Bhakti. K., \& Wiwit. T. (2018). Strategi Pembelajaran Biologi Berbasis Lingkungan Melalui Kombinasi Pembelajaran Indoor Dan Outdoor Sebagai Upaya Meningkatkan Keterampilan Proses Siswa SMA.Prosiding Seminar Nasional Pendidikan Biologi. 1 (1): 
148-155. (online). (http://jurnalfkip.unram.ac.id/inde x.php/SemnasBIO/article/viewFile/ 588/536), diakses 1 Juli 2019.

Zukmadini, A.Y., B. Karyadi., R.Z. Ekaputri., N. Anggraini., A. Ruyani., W. Trisnawati., dan M. Suterisni. (2018). The trend of high school students participation behavior toward conservation of aquatic ecosystem. Journal of Physics. 11 (16): 1-6. (online). (https://iopscience.iop.org/article/
$10.1088 / 1742-$ 6596/1116/5/052081/pdf), diakses 23 Juli 2019.

Zulkifli, H \& Doni, S. (2011). Struktur Komunitas Makrozoobentos di Perairan Sungai Musi Kawasan Pulokerto sebagai Instrumen Biomonitoring. Jurnal Natur Indonesia. 14 (1): 95-99. (online). (https://ejournal.unri.ac.id/index.p $\mathrm{hp/JN/article/download/202/196),}$ diakses 13 Juli 2019. 